Bangladesh J. Zool. 42(2): 261-269, 2014

\title{
PRODUCTION PERFORMANCES OF MONOSEX NILE TILAPIA, OREOCHROMIS NILOTICUS IN BRACKISHWATER PONDS
}

\author{
S.B. Saha* and M. S. Khatun \\ Bangladesh Fisheries Research Institute, Brackishwater Station, \\ Paikgacha, Khulna-9280, Bangladesh.
}

\begin{abstract}
Production feasibility of monosex nile tilapia, Oreochromis niloticus was studied in eight brackishwater ponds, where tilapia fries with the average body weight (ABW) of $0.15 \mathrm{~g}$ were stocked at a density of $5 / \mathrm{m}^{2}$. Salinity of the ponds varied from $11 \mathrm{ppt}$ to $14 \mathrm{ppt}$. Fishes was fed with floating feed containing $35 \%$ crude protein. After 105 days of culture, production of tilapia was 6334.20$8099.50 \mathrm{~kg} / \mathrm{ha}$ with an average mean of $7456.35 \pm 589.60 \mathrm{~kg} / \mathrm{ha}$. This production was achieved when average body weight and survival of tilapia was $176.50 \pm 18.44$ $\mathrm{g}$ and $84.42 \pm 7.23 \%$, respectively. This growth and production tilapia was higher and very much comparable to the production of tilapia reported from freshwater bodies. The study indicates that tilapia can be grown as crop diversification in brackishwater ponds, where stocking of shrimp now become risky due to invasion of diseases.
\end{abstract}

Key words: Production, nile tilapia, monosex, brackishwater, Bangladesh

\section{INTRODUCTION}

Tilapias are considered as 'wonder fish' by some and as 'aquatic chicken' by others as opined by Gupta et al. (1992). Expect that tilapia would act as a miracle fish in aquaculture. Mozambique tilapia, Oreochromis mossambicus was introduced to Bangladesh from Thailand in 1954 (Rahman 1985). But due to prolific breeding nature and vegetative feeding behaviour, the distribution and culture of this fish did not get that much popularity among the farmers as expected. Later on, Bangladesh Fisheries Research Institute (BFRI) imported Nile tilapia, O. niloticus from Thailand in 1986 (Gupta et al. 1992) and developed culture technology of this fish (Hussain 1989). Development of Genetically Improved Farmed Tilapia (GIFT) by ICLARM (Eknath et al. 1993), and its introduction to Bangladesh in 1994 and further development of the strain by BFRI (Hussain and Kohinoor 2003) paved the way of getting much popularity of tilapia throughout the country. Tilapias, despite being freshwater fish, are believed to have been evolved from marine ancestors (Kirk 1972). It is no surprise that most of these fishes are able to tolerate a wide range of salinity. Tsadik and Bart (2007) reported that the Nile tilapia, O. niloticus is a widely cultured fish because it can grow and reproduce in a wide range of environmental conditions and tolerate stress induced by handling.

*Author for correspondence: <sbikashsaha@yahoo.com>. 
Production of nile tilapia from ponds of Bangladesh was 8,221 MT which was only $1.52 \%$ of total pond fish production in 2001-2002. This production has increased to 98,758 MT which is $8.10 \%$ of total pond fish production in 2010-11 (FRSS 2012). Obviously, the existing production will be much higher. There are about 2,75,232 ha shrimp farm in Bangladesh (DoF 2013). Out of these, $2,15,232$ ha is brackishwater impoundments locally called ghers. These waterbodies are generally used for culture of brackishwater shrimp, Penaeus monodon. But due to continuous invasion of viral disease, production of shrimp in the coastal ghers is being interrupted to a great extent since 1994 (Hossain 1996). As a tool of risk management and to make coastal aquaculture resilient, productive and ensuring income, diversification of production practices have been suggested by Green (1997), Ravisankar et al. (2005) and Sathiadhas et al. (2006). Hussain (2004) suggested that commercial farming of tilapia could be an alternative in brackishwater ponds where shrimp culture was in collapse due to disease outbreak.

Bangladesh Fisheries Research Institute (BFRI) conducted several studies on the diversification of crops in coastal ghers with different species of fishes at low density in combination with shrimp (Ali et al. 2000, Shofiquzzoha et al. 2001 and BFRI 2008). Saha et al. $(2009,2012)$ cultured mixed sex of GIFT with Penaeus monodon in brackishwater ghers at low density $\left(1 / \mathrm{m}^{2}\right)$ with $P$. monodon and at a salinity level 8-16 ppt. with the objective of minimizing the risk of losing investment in case of mortality of shrimp due to invasion of virus in coastal shrimp farms.

Growth of male tilapia is approximately twice as fast as females. Moreover, the presence of female tilapia leads to uncontrolled reproduction, excessive recruitment of fingerlings, competition for food, and stunting of the original stock, which may not reach marketable size. Culture of monosex tilapia is postulated to solve this problem (Guerrero 1982). Therefore, the male monosex population of tilapia is being used for commercial culture. In this context, the present study was carried out to evaluate the production performance of male $O$. niloticus at high density in the brackishwater ghers of the coastal Bangladesh.

\section{MATERIAL AND METHODS}

The study was conducted in 8 earthen ponds of $1000 \mathrm{~m}^{2}$ each of the Bangladesh Fisheries Research Institute, Brackishwater Station, Paikgacha at a uniform density of 5 nile tilapias $/ \mathrm{m}^{2}$. A temporary in-pond nursery $\left(25 \mathrm{~m}^{2}\right)$ was prepared at one corner in each pond by erecting nylon net fastened in bamboo frame. Soil of each pond was sun-dried and treated with lime $(\mathrm{CaO} @ 250 \mathrm{~kg} / \mathrm{ha})$. 
All ponds were filled with $11 \mathrm{ppt}$ tidal water of Shibsa river up to a depth of one meter after filtering through nylon net. Water of the ponds was treated with rotenone@1.5 ppm to kill unwanted and predatory fishes. Dolomite@20 ppm was applied to each pond to increase buffer capacity of the ponds. After three days, water of the ponds was fertilized with urea and TSP @ 2.5 ppm and 3.0 ppm, respectively. After growth of sufficient plankton, required quantity of fries (ABW, $0.15 \mathrm{~g}$ ) of male Nile tilapia, O. niloticus were stocked to the in-pond nursery of each pond. The procured fries were produced and transported in freshwater. Before stocking, fries were acclimatized to the pond water gradually for one hour. In the nursery, the stocked fries of tilapia were fed with commercial powder feed (containing 35\% protein) @ 20\% of total tilapia biomass. After 15 days of nursing, fishes were released to the whole pond by up-folding the nylon net of the nursery. At this stage, fishes were fed with floating crumble feed (30\% protein) @ 10\% of total fish biomass. After fifteen days onwards, ball shaped floating feed containing $30 \%$ protein was supplied to the fishes. The feeding rate was gradually reduced to $3.0 \%$ at the end of the culture period. Growth of fishes was monitored at fortnight interval and feed was adjusted accordingly. Feed was supplemented with probiotics to increase feeding efficacy. Specific growth rate (SGR), feed conversion ratio (FCR) and protein efficiency ratio (PER) were calculated following the equation as cited by Pechsiri and Yakupitiyage (2005). The equations are as follows:

Specific growth rate $(\mathrm{SGR} \%)=[(\ln$ final weight $-\ln$ initial weight $) /$ time $($ days $)] \times 100$

Feed conversion ratio $(\mathrm{FCR})=$ total amount $(\mathrm{g})$ of dry feed supplied/wet weight $(\mathrm{g})$ gain of fish.

Protein efficiency ratio $(\mathrm{PER})=$ Weight gain $(\mathrm{g}) /$ protein consumed $(\mathrm{g})$

Water quality variables viz., temperature, depth, salinity, $\mathrm{pH}$, transparency and total alkalinity were determined at weekly intervals and dissolved oxygen (DO) was determined frequently following standard methods (APHA 1992). After 85 days of culture, $20 \%$ water of all ponds was exchanged with tidal water to reduce the organic load of the ponds. After 105 days of culture, when demand for oxygen became very high and level of dissolved oxygen in the morning reduced to lowest level even after exchange of water, all fishes were harvested by draining out ponds and growth and production were estimated. Statistical analyses were done using Microsoft Office Excel 2007 software.

\section{RESULTS AND DISCUSSION}

Water quality parameters: During the culture period, temperature of water was $28.0-33.5^{\circ} \mathrm{C}$ and almost same in all ponds. Depth of water was maintained 
at a level of one meter in all ponds by draining out the excess monsoon water and refilling the evaporated water with the water from the adjacent tidal canal. As shown in Fig. 1a, salinity of water was also almost same in all ponds and varied from $11 \mathrm{ppt}$ to $14 \mathrm{ppt}$. Salinity was lowest during stocking and increased to the highest level of 13-14 ppt at 40-45 days of culture and again gradually decreased to lowest level at the end of culture period due to monsoon rain. Transparency of water was initially higher in all ponds and gradually decreased


Fig. 1. Variation in some water quality parameters of the experimental ponds of nile tilapia.

with the progress of culture period (Fig. 1b). $\mathrm{pH}$ of water of all ponds was alkaline throughout culture period and varied from 7.7-9.0 (Fig. 1c). Dissolved oxygen (DO) concentration was very close in different ponds. Initial level of morning DO was 4.30-5.50 mg/1 which gradually decreased to less than $1 \mathrm{mg} / 1$ at 84 days of the culture period (Fig. 1d). This trend in DO concentration might be due to higher demand of oxygen by the increased biomass of fish with the 
progress of culture period. Besides, increased excreta of fish might be demanded higher oxygen for stabilization.

Though no mortality of tilapia was observed at the this level of DO, fishes were observed to surfacing in the morning. At this stage, $20 \%$ of water of all ponds was exchange with tidal water to improve the situation. Even then after one week, DO again decreased to near about $1.0 \mathrm{mg} / 1$ in the morning. At this stage, the culture was discontinued and all fishes were harvested. As shown in Fig. 1e, variation pattern in alkalinity was almost same in all ponds and alkalinity varied from 116 to $196 \mathrm{mg} / 1$ indicating high potential for primary production.

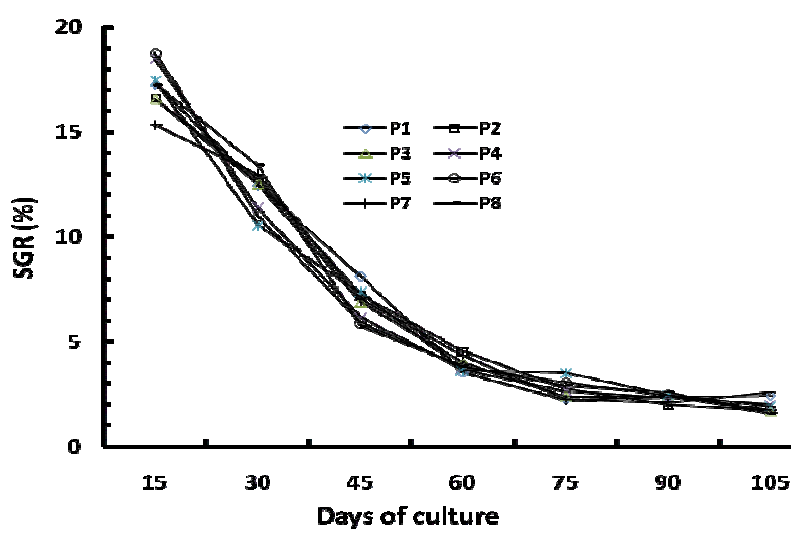

Fig. 2. Specific growth rate (SGR) of male nile tilapia (Oreochromis niloticus) at $5 / \mathrm{m}^{2}$ density in brackishwater ponds.

Growth and production of fish: Growth and production performance of tilapia have been shown in Table 1 . Average body weight (ABW) of fry of tilapia during stocking was same of $0.15 \mathrm{~g}$ in all ponds. After 105 days of culture, tilapia attained an $\mathrm{ABW}$ of $162-215 \mathrm{~g}$ with a mean of $176.50 \pm 18.44 \mathrm{~g}$. Daily weight increment varied from 1.55 to $2.05 \mathrm{~g}$ in different ponds with the mean of $1.68 \pm 0.18 \mathrm{~g}$. There is no significant difference among the specific growth rate (SGR) of tilapia in different ponds. As shown in Fig. 2, SGR was highest of $15.35-18.7 \%$ in the $1^{\text {st }}$ fortnight in the nursery of different ponds. The SGR decreased with the progress of culture period and decreased sharply to 3.554.55 up to 60 days of culture. After then, the SGR was almost horizontal for the rest of the culture period and ultimately decreased to $1.55-2.59 \%$ in the last fortnight of culture. The SGR of tilapia after 105 days of culture was $6.65-6.80 \%$ with a mean of $6.73 \pm 0.10 \%$. As could be seen from Table 1, survival of tilapia was $75.4-93.20 \%$ with the mean survival of $84.42 \pm 7.23 \%$. After 105 days of culture, the range of production of monosex nile tilapia was 6334.20-8099.50 
$\mathrm{kg} / \mathrm{ha}$ with a mean of $7456.35 \pm 589.60 \mathrm{~kg} / \mathrm{ha}$. For this production, $7,026-$ $10,109 \mathrm{~kg}$ feed was required with the feed conversion ratio of 1.11-1.27 $(1.21 \pm 0.05)$. Protein efficiency ratio for this production of tilapia was 2.81-3.97 with the mean of $3.09 \pm 0.38$.

Table 1. Production performance of male Oreochromis niloticus in brackishwater ponds.

\begin{tabular}{cccccc}
\hline Pond Nos. & $\begin{array}{c}\text { Average body } \\
\text { wt. }(\mathrm{g})\end{array}$ & $\begin{array}{c}\text { Survival } \\
(\%)\end{array}$ & $\begin{array}{c}\text { Production } \\
(\mathrm{kg} / \mathrm{ka})\end{array}$ & $\begin{array}{c}\text { Feed } \\
\text { conversion } \\
\text { ratio (FCR) }\end{array}$ & $\begin{array}{c}\text { Protein } \\
\text { efficiency ratio } \\
\text { (PER) }\end{array}$ \\
\hline 1 & 215.00 & 75.34 & 8099.05 & 1.20 & 3.97 \\
2 & 189.50 & 78.66 & 7453.04 & 1.24 & 2.88 \\
3 & 165.00 & 92.80 & 7656.00 & 1.18 & 3.02 \\
4 & 170.00 & 79.74 & 6777.90 & 1.23 & 2.90 \\
5 & 163.00 & 93.20 & 7595.80 & 1.11 & 3.22 \\
6 & 183.00 & 87.00 & 7960.50 & 1.19 & 3.00 \\
7 & 162.00 & 78.20 & 6334.20 & 1.23 & 2.90 \\
8 & 165.00 & 90.38 & 7456.35 & 1.27 & 2.81 \\
Mean \pm SD & $176.50 \pm 18.44$ & $84.42 \pm 7.23$ & $7456.35 \pm 589.60$ & $1.21 \pm 0.05$ & $3.09 \pm 0.38$ \\
\hline
\end{tabular}

It has been observed that growth of tilapia in brackishwater is not less than that of freshwater. In the brackishwater pond, daily weight gain of monosex tilapia was found to be $1.54-2.05 \mathrm{~g}$ by rearing for 105 days at $5 / \mathrm{m}^{2}$ density and supplemented with floating feed. Whereas in freshwater ponds, Hussain et al. (2000) reported daily weight gain of $0.71 \mathrm{~g}$ for GIFT reared for a period of 180 days and fed with rice bran and Ahmed et al. (2013) reported a daily weight gain of $1.56 \mathrm{~g}$ using prepared feed and $1.78 \mathrm{~g}$ using commercial feed for monosex tilapia reared for 70 days. So daily weight gain of tilapia using floating feed in brackishwater ghers is very much comparable to that of freshwater ponds. In freshwater system, Green (1992) obtained SGR of tilapia as 2.03\% using feed and fertilizer in Handurus, Diana et al. (1996) recorded SGR of O. niloticus as $3.10 \%$ using feed and fertilizer in Thailand. In Bangladesh, Hossain et al. (2004) estimated SGR of $2.04-2.03 \%$ of GIFT fed with formulated feed (30.09\% protein) and Ahmed et al. (2013) reported SGR of monosex tilapia as $3.09 \%$ using prepared feed (55.24\% protein) and $2.97 \%$ using commercially available feed. In the present investigation, SGR of monosex tilapia was $6.73 \%$, which is higher than freshwater systems. Survival of tilapia in the present study (75.40-93.20\%) in brackishwater system is also comparable to that of freshwater systems of 75.55-90.37\% as recorded by Ahmed et al. (2013). Mortality of tilapia fry, which was produced and transported in freshwater and stocked to 11 ppt water after one hour acclimatization showed insignificant mortality. FCR depends on quality of supplied food and also on quality of water of the system. However, FCR of monosex tilapia in the present investigation was 1.11-1.27, which is lower than that of 1.71-1.77 for GIFT as reported by Hossain et al. (2004) and 1.40-1.51 for 
monosex tilapia as reported by Ahmed et al. (2013) in freshwater ponds. The lower FCR in the present investigation may be due to application of floating feed supplemented with probiotics. In the present study, production of monosex tilapia was $6334.20-8099.05 \mathrm{~kg} / \mathrm{ha} / 105$ days. This production is much higher than that of $4000-6000 \mathrm{~kg} / \mathrm{ha} / 120-180$ days that has been estimated by Hussain (2004) in semi-intensive culture system in freshwater ponds.

Considering growth, SGR, production and FCR, it can be stated that the vast coastal brackishwater impoundments can be effectively used for culture of nile tilapia. For intensified culture system, exchange of water is needed at least at the later stage of culture period to maintain a congenial culture environment by reducing organic load of the culture system. In freshwater ponds, there is very little scope of water exchange due to lack water source. As most of the coastal impoundments are very adjacent to tidal river, water management can be suitability done in brackishwater system. Contribution of nile tilapia for enhancement of production in the fishery sector of Bangladesh is increasing day by day. This fish is now being extensively cultured in the diverse freshwater systems mostly in ponds. Introduction of nile tilapia in the brackishwater impoundments can enhance the national fish production to a significant level.

\section{LITERATURE CITED}

AHMED, G.U., SULTANA, N., SHAMSUDDING, M. and HOSSAIN, M.B. 2013. Growth and production performance of monosex tilapia (Oreochromis niloticus) fed with homemade feed in earthen mini ponds. Pakistan J. Biol. Sci. DOI: 10. 3923/pjbs. 1-5 p.

ALI, M.S., SHOFIQUZZOHA, A.F.M. and AHMED, S.U. 2000. Observation on the production performance of Penaeus monodon with Liza parsia under different cropping system. Bangladesh J. Fish. Res. 4(2):141-145.

APHA. 1992. Standard Methods for the Examination of Water and Waste Water. 18th ed., American Public Health Association (APHA), Washington, D.C.

BFRI (Bangladesh Fisheries Research Institute). 2008. Annual report 2005-06 and 2006-07. Bangladesh Fisheries Research Institute, Mymensingh-2201. 154 p.

DE. SCHRIJVER, R. and OLLEVIER, F. 2000. Protein digestion in Juvenile turbot (Scophthalmus maximus) and effects of dietary administration of Vibrio proteolyticus. Aquaculture 86: 107-116.

DIANA, J.S., LIN, C.K. and YI, Y. 1996. Timing of supplemental feeding for tilapia production. J. World Aquacult. Soc. 27: 410-419.

DOF. 2013. National Fish Week 2013 compendium (in Bengali). Department of Fisheries (DoF), Ministry of Fisheries and Livestock, Bangladesh. 144 p.

EKNATH, A.E., TAYAMEN, M.M., PALADA-DE-VERA, M.S., DANTING, J.C., REVES, R.A., DIONISIO, E.E., CAPILI, J.B., BILIVAR, H.L., ABELlA, A.T., CIRCA, A.V., BENTSEN, H.B., GJEDREM, T. and PULLIN, R.S.V. 1993. Genetic improvement of farmed tilapia: the growth performances of eight strains of Oreochromis niloticus tested in different farm environments. Aquaculture 111: 171-188. 
FRSS. 2012. Fisheries Statistical Yearbook of Bangladesh. Fisheries Resources Survey System (FRSS), Department of Fisheries, Bangladesh. 46p.

GREEN, B. W. 1992. Substitution of organic manure for pelleted feed in tilapia production. Aquaculture 101: 213-222.

GREEN, B.W. 1997. Inclusion of tilapia as a diversification strategy for penaeid shrimp culture. In IV Symposium on Aquaculture in Central America: Focusing on Shrimp and Tilapia, 22-24 April 1997, at Tegucigalpa, Honduras. (eds. Alston, D. E., Green, B. W. an Clifford, H. C.). Asociacion Nacional de Acuicultores de Honduras and the Latin American Chapter of the World Aquaculture Society. p. 84-93.

GUPTA, M. V., AHMED, M., BIMBAO, M. P and LIGHTFOOT, C. 1992. Socio-economic impact and farmers assessment of Nile tilapia (Oreochromis niloticus) culture in Bangladesh. International Centre for Living Aquatic Resource Management (ICLARM), Tech Rep. 35: 50p.

GUERRERO, R. D. III.1982. Control of tilapia reproduction. In The biology and culture of tilapias. (eds. Pullin, R. S. V. And Lowe-McConnel, H. R.) ICLARM Conference proceedings 7. International Center for Living Aquatic Resources Management, Manila, Philippines. p. 309316.

HOSSAIN, M. A. 1996. Epidemic type shrimp and fish disease in Bangladesh. In Proceedings of the $1^{\text {st }}$ ODA SEAADCP network meeting. (ed. MACRAE, I. H.) Aquatic Animal Health Research Institute, Bangkok. p. 21-27.

HOSSAIN, M. A., ROY, R., RAHMATULLAH, S. M. and KOHINOOR, A. H. M. 2004. Effect of stocking density on the growth and survival of GIFT tilapia (Orechromis niloticus) fed on formulated diet. J. Agric. Rural Dev 2: 127-133.

HUSSAIN, M. G. 1989. A manual on improved technique of nilotica culture in ponds. Extension Material Series No. 2. Fisheries Research Institute, Mymensingh, Bangladesh. 149 p.

HUSSAIN, M. G. 2004. Farming of tilapia: Breeding plans, mass seed production and aquaculture techniques. Published by H. A. Hussain, 55 Kristapur, Mymensingh, Bangladesh. 149 p.

HUSSAIN, M. G. and KOHINOOR, A. H. M. 2003. Breeding, monosex male tilapia seed production and culture technologies of BFRI super tilapia. Extension Manual No. 25. Bangladesh Fisheries Research Institute, Mymensingh.

HUSSAIN, M. G., KOHINOOR, A. H. M., ISLAM, M. S., MAHATA, S. C. and ALI, M. Z. 2000. Genetic evaluation of gift and existing strain of Nile tilapia, Orechromis niloticus L., under on-station and on-farm conditions in Bangladesh. Asian Fish. Sci. 13:117-126.

KIRK, R. G. 1972. A review of the recent development in tilapia culture with special reference to fish farming in the heated effluents of power stations. Aquaculture 1:45-60.

PECHSIRI, J. and YAKUPITIYAGE, A. 2005. A comparative study of growth and feed utilization efficiency of sex-reversed diploid and triploid Nile tilapia, Orechromis niloticus L. Aquacult Res., 36:45-51.

RAVISANKAR, T., SARADA, C. and KRISHNAN, M. 2005 Diversification of fish culture and exports among major shrimp-producing countries of Asia: A spatial and temporal analysis. Agricult. Econ. Res. Rev. 18:187-195.

RAHMAN, A. K. A. 1985. Introduction of Exotic Fishes in Bangladesh. Fisheries Research and Training Centre, (booklet). Department of Fisheries, Chandpur, Bangladesh.

SAHA, S. B., MONIRUZZAMAN, M., ALAM, M. J. 2009. Optimization of stocking density of black tiger shrimp (Penaeus monodon) for concurrent culture with genetically improved farmed tilapia (GIFT) in brackishwater ghers. Bangladesh J Zool. 37(1): 175-182. 
SAHA, S. B., MONIRUZZAMAN, M. and ALAM, M. J. 2012. Concurrent culture of shrimp and tilapia in coastal pond. Bangladesh J. Agricul. 37(1):11-16

SATHIADHAS, R., JOSEPH, J. and JERSON, S. 2006. Diversification of aquaculture for empowerment to fisheries through institution village linkage programme (IVLP) in Kerala, India. Naga 29 (3 \& 4):78-87.

SHOFIQUZZOHA, A.F.M., ISLAM, M.L. and AHMED, S.U. 2001. Optimization of stocking rates of shrimp (Penaeus monodon) with brackishwater finfish in a polyculture system. Online J. Biol. Sci. 1(8): 694-697.

TSADIK, G.G. and BART, A.N. 2007. Effects of feeding, stocking density and water-flow rate on fecundity, spawning frequency and egg quality of Nile tilapia, Oreochromis niloticus. Aquaculture 275:152-162.

(Manuscript received on 11 February, 2014; revised on 11 November, 2014) 